\title{
Casualisation of Labour in Academic Libraries: Experience of Babcock University Library
}

\author{
Glory Onoyeyan \\ Babcock University Law Library, Iperu-Remo, Ogun State, Nigeria \\ Email: gloryonoye@yahoo.com
}

Received 15 June 2015; accepted 30 June 2015; published 9 July 2015

Copyright (C) 2015 by author and OALib.

This work is licensed under the Creative Commons Attribution International License (CC BY). http://creativecommons.org/licenses/by/4.0/

(c) (i) Open Access

\section{Abstract}

This paper explored casualisation of labour in academic libraries and its effect on employees. Although casualization of labour is mainly for the unskilled and for those with low educational qualification, it has become a growing concern as persons with skilled and specialized training are being subject to casualization. Academic libraries in Nigeria do not spare the scourge of casual employment. Through the analysis of literature, the paper took a look on casualization of labour in academic libraries, drawing on the experience of Babcock University library. It employed data gathered from questionnaire administered on the 21 casual employees in Babcock University library. Findings show that casual labour is fraught with negative effects. The study also found that Babcock University library is largely casualised. Casual workers at Babcock University library are however satisfied with their work; they enjoy health benefits and have the opportunity for career progression.

\section{Keywords}

Casualisation, Casual Work, Academic Libraries, Babcock University

Subject Areas: Library, Intelligence, Philology

\section{Introduction}

Casual work has always existed for particular jobs, especially jobs that are routine in nature. It also covers persons that are unskilled and those with low educational qualification. Kalejaiye [1] notes that in the past, casual labour was required for seasonal work or work that arises periodically and continues for a relatively short period. However, casualization of labour is recently taking an alarming dimension as both skilled and unskilled labour are engaged as casual workers in all sectors of the economy. 
In Nigeria, there is a growing concern that the use of local casual workers in organisations is on the increase, with hosts of undesirable consequences for those who are compelled by unemployment and poverty to take such employment [2]. Casual labour in addition to providing cheap labour to the benefits of the employers is also a violation of labour regulations.

\section{Objective of the Study}

The objective of the study is to examine casualization of labour in academic libraries. The study specifically will

1) examine the level of satisfaction of casual workers with their work;

2) highlight the attitude of casual workers to their work;

3) ascertain the reason for casual work.

\section{Review of Literature}

\subsection{Casualisation of Labour}

According to Kalejaiye [1], there is no standard definition of casual work. Casual labour can be defined severally as work that is short-term or temporary, involving irregular hours and not guaranteed to be ongoing. Casual employees do not usually work set hours, although some casual workers do work long, regular hours. Casual workers are also often employed on an "as needed" basis. Some casual workers may experience long periods of time between being offered shifts. Bamidele [3] notes that a plethora of terms have been deployed to define and account for the growth of this type of irregular employment contract.

Traditionally, casual labour is work conducted for defined period and during peak business period. Casual workers will be called to supplement full time workers in times of high business activity [4]. Sheen [5] defines a casual job as a job without paid leave entitlements, but the essence of a casual job is that the worker is entirely expendable on an hour-to-hour, week-to-week, year-to-year basis. Day and Buultjens [6] agree when they opine that casual employment can be defined in terms of its lack of entitlements usually associated with permanent employment. Casualization captures the phenomenal growth on non standard employment globally. Okafor [2] is also of this thought when he asserts that in recent decades there has been a dramatic increase in nonstandard jobs due to such factors as: massive unemployment, globalisation, the shift from the manufacturing sector to the service sector and the spread of information technology. These changes have created a new economy which demands flexibility in the workplace and, as a result, caused the decline of the standard employment relations and a dramatic increase in precarious work

Fourie [7] sees the current labour market as a market which has many forms of employment relations that differ from full-time employment. These include part-time employees, temporary employees, employees supplied by employment agencies, casual employees, home workers and workers engaged in a range of contracting relationships. They are usually described as non-standard or atypical employees.

In Nigeria, the term is used to describe work arrangements that are characterized by bad work conditions like job insecurity, low wages, and lack of employment benefits that accrue to regular employees as well as the right to organize and collectively bargain [1]. Okafor [2] points out that workers in this form of work arrangement can be dismissed at any time without notice and are not entitled to redundancy pay. It is an unprotected form of employment, because it does not enjoy the statutory protection available to permanent employees. Okafor [2] also argues that in developing societies like Nigeria which is bedeviled by the crisis of development and where labour market is saturated, most employers' intention to keep cost of labour as low as possible has resulted in the proliferation in nonstandard employment relations such as contract work, casual work or part time work even though workers in these categories have prerequisite skills to hold full time jobs with varying implications for decent work deficits.

\subsection{Effects of Casualisation of Labour}

Casual employees also described as non-standard or atypical employees are particularly vulnerable to exploitation because they are unskilled or work in sectors with little or no trade union organisation or little or no coverage by collective bargaining. They frequently have less favourable terms of employment than other employees performing the same work, as well as less security of employment and they often do not receive "social wage" benefits such as medical aid, pension or provident funds. These employees therefore depend upon statutory em- 
ployment standards for basic working conditions [7].

In Nigeria, the trend of casualisation of labour is increasing at an alarming rate in all as evidence shows that most organisations are downsizing, and restructuring, a process that has created feelings of insecurity among workers and fuelled by the government's uncertain economic and political reforms.

Day and Buultjens [6], Bodibe [4] and Kalejaiye [1] succinctly highlighted the effects of casualization of labour to include:

1) Insecurity of employment. Employment of casual workers can be terminated at any time without notice.

2) Lower average earnings than equivalent permanent workers. This may occur whether or not the casual workers have the same level of skill or qualification with the regular worker.

3) Unpredictability of income. Hours of work may be varied at the discretion of the employer which affects the income of the workers.

4) Reduced access to adequate training and career advancement opportunities. To cut organizational cost, organizations that deploy casual labour do not invest in their training and development.

5) Low organisational commitment. As a result of poor treatment by organisations, casual workers do not employ maximum commitment to their work.

6) Lack of social benefits. Casual are not entitled to vacation. When they do take vacation, it is at their cost.

7) Poor working conditions.

8) There are disparity in the conditions of permanent, casual and subcontracted worker thereby causing divisions and poor work relationships.

9) Detachment from their jobs.

10)Lack of social protection, like the pension scheme.

11)Lack of rights and minimal legal status of casual work. This threatens access to resources and entitlements, and threatens self-respect that equal rights supports.

12)Casual workers lack access to career paths, because much casual work lacks possibilities for career progression comparable to standard employment.

\subsection{Casualisation of Labour in Academic Libraries}

Okafor [2] has noted that in Nigeria, the problem of nonstandard employment is very common in many establishments whether indigenous, transnational or multi-national firms, either public or private industry, including telecommunications sector, oil and gas sector, power sector, banking sector, education sector, and so on.

Academic libraries in Nigeria are not spared the scourge of casual employment. The library is a key player in the provision of information to meet varied needs of members of the society. Libraries as educational agency is poised to ensure that knowledge is acquired and disseminated and to ensure that equal access to information is enjoyed by all. Academic libraries facilitate the reading, studying and research needs of their clienteles. They are the nerve centre of every higher educational institution. They have been institutional repositories that house the knowledge base of generations and they help to build capacities for nations. Kharamin and Siamian [8] citing Machell (1996), stated that the ideal library service is one where each individual, has access to the materials and information at the time they are required, in a format that can be used, in the quantities that are needed, and where the needs of the user are understood by the staff. Kharamin and Siamian [8] argue that the systematic organization of knowledge in the library requires skills, and getting people to utilize organized information require training. Itsekor and Oyewole [9] assert that workers in academic libraries are employed and empowered to meet the information needs of both staff and students of the higher institutions and the communities where they are established. Patrons most times need to get information on their finger tips but they are not able to because they do not know how the library resources are organized and how to access them.

Considering the value of information to development, planning and decision making, it is important that workers charged with the responsibility of managing information be committed to discharge these duties with satisfaction. Tella, Ayeni and Popoola [10] highlighted strategies that can be used to motivate library personnel to enjoy satisfaction with their work. These include good salary, good conditions of service, and training which will give the library workers opportunities for self-improvement and development to meet the challenges and requirements of new techniques of performing a task. Itsekor and Oyewole [9] also argue that library workers now have the opportunity to use modern tools to provide quicker, more complete, and more sophisticated services to their users. They must therefore retool in order for them to be able to manage successful library services. 
Therefore, training and retraining is pertinent for all library workers.

As correctly noted, casualization of labour has invaded every sector, including libraries. Due to globalisation and the spread of information technology, a new kind of rational organisations that emphasize flexibility in the labour market and in employment relationships have been created. These influences have resulted in the prevalence of employment of casual workers also in the library. Jobs in the library that are routine, and permanent in nature have been casualised.

\subsection{Babcock University Library Experience}

Ugboma and Edewor [11] opined that libraries in higher institutions of learning are aimed at supporting the objectives of their institution, which has to do with learning, teaching, research and service. This is done by assembling, organizing, and disseminating a wide range of information resources in all formats. Library and information service provision has witnessed a paradigm shift from purely traditional, physical manipulation of information resources to technological manipulation as well as electronic provision of library and information service. It is pertinent to note that academic libraries need to integrate into this changing environment given the high exceptional regard that is placed on information as a veritable resource. Library workers need to enjoy labour relations that would propel them to discharge their responsibility with due diligence and high level of commitment.

Babcock University library has a current staff strength of 35 workers for the 2014/2015 academic session. Fourteen of these 35 are on regular full time employment while 21 are casual workers.

\section{Methodology}

Questionnaires were administered to the 21 casual workers to assess their satisfaction with their work as casual workers in Babcock University library. The questionnaire elicited data on the length of time they have been in the employ of Babcock University library, their educational qualification, their age, and so on. Also, their level of satisfaction with work-related issues was assessed. The 21 questionnaires administered were filled and returned. Results are presented in tables below:

Table 1 which captured the demographic information of the respondents indicates that most of the casual workers have been working in the Babcock University library between one to three years. It also shows that $57.14 \%$ of casual workers in the Babcock University library are SSCE holders, 19.04\% are OND holders, 14.3\% are NCE holders while $9.52 \%$ are bachelor degree holders. The table reveals that more of the casual workers in Babcock University library are between the age of 18 and 29 with $61.9 \%$ indication while $33.3 \%$ are between the age range of 30 - 39. The table also shows that there are more female among casual workers in Babcock University library with $61.9 \%$ indication while $38.1 \%$ are males.

From Table 2, 61.9\% of casual workers in Babcock University library do not consider casual labour as a bridge to permanent employment while $23.8 \%$ considers casual labour as a bridge to permanent employment. $57.14 \%$ indicated that they have received some training since employment at the BU library, while $38.1 \%$ indicated that they have not received some training since employment. $66.6 \%$ indicate that they enjoy health benefits/health insurance, while $23.8 \%$ showed that they do not enjoy health benefits. $66.6 \%$ shows that they have possibilities for future career progression at the library, while $23.8 \%$ indicated that they do not have possibilities for future career progression in the library. $47.6 \%$ indicates that they feel treated less fairly than permanent (regular) employees with another $47.6 \%$ indicating that they do not feel treated less fairly than permanent (regular) employees. $4.76 \%$ did not give any response to this. $47.6 \%$ indicated that they do not feel exploited at the expense of permanent (regular) employees while 33.3\% showed that they feel exploited. 19.04\% did not respond.

Table 3 shows that while $4.76 \%$ indicate that they are completely dissatisfied with their work in the library, $14.3 \%$ shows they are completely satisfied, while $61.9 \%$ indicates that they are satisfied. $47.6 \%$ shows that they are completely dissatisfied with their salary, $4.76 \%$ shows they are dissatisfied, while $9.52 \%$ indicate that they are satisfied, 33.3\% were neural about their satisfaction/dissatisfaction. While $19.04 \%$ are completely dissatisfied, $14.3 \%$ are dissatisfied with their career progression at the library, $14.3 \%$ are completely satisfied with their career progression at the library, while $28.6 \%$ are satisfied. $23.8 \%$ are completely dissatisfied with the vacation time they receive, $19.04 \%$ are dissatisfied, while $9.52 \%$ are completely satisfied, with $23.8 \%$ indicating that they are satisfied. $14.3 \%$ shows they are completely satisfied with the medical insurance and $38.1 \%$ indicates that they are satisfied. There was no indication of dissatisfaction with medical insurance. 
Table 1. Demographic information of respondents.

\begin{tabular}{|c|c|c|}
\hline \multicolumn{3}{|c|}{ Length of employment of casual workers at Babcock University library } \\
\hline Years & Frequency & Percentage \\
\hline Less than 1 year & 6 & 28.6 \\
\hline 1 - 3 years & 7 & 33.3 \\
\hline 4 - 6 years & 3 & 14.3 \\
\hline More than 6 & 5 & 23.8 \\
\hline \multicolumn{3}{|c|}{ Educational qualification of casual workers in Babcock University library } \\
\hline Qualification & Frequency & Percentage \\
\hline SSCE & 12 & 57.14 \\
\hline OND & 4 & 19.04 \\
\hline HND & - & - \\
\hline NCE & 3 & 14.3 \\
\hline Bachelors & 2 & 9.52 \\
\hline Masters & - & - \\
\hline \multicolumn{3}{|c|}{ Age category of casual workers in Babcock University library } \\
\hline Age & Frequency & Percentage \\
\hline $18-29$ & 13 & 61.9 \\
\hline $30-39$ & 7 & 33.3 \\
\hline $40-55$ & - & - \\
\hline $55^{+}$ & - & - \\
\hline No response & 1 & 4.76 \\
\hline \multicolumn{3}{|c|}{ Gender distribution of casual workers in Babcock University library } \\
\hline Gender & Frequency & Percentage \\
\hline Male & 8 & 38.1 \\
\hline Female & 13 & 61.9 \\
\hline
\end{tabular}

Table 2. Attitude of casual workers in Babcock University library towards status.

\begin{tabular}{|c|c|c|c|c|c|c|}
\hline Attitude & Yes & $\%$ & No & $\%$ & NR & $\%$ \\
\hline $\begin{array}{l}\text { Do you consider casual labour as } \\
\text { a bridge to permanent employment? }\end{array}$ & 5 & 23.8 & 13 & 61.9 & 3 & 14.3 \\
\hline $\begin{array}{l}\text { Have you received any training since } \\
\text { employment at the BU library? }\end{array}$ & 12 & 57.14 & 8 & 38.1 & 1 & 4.76 \\
\hline $\begin{array}{l}\text { Have you received any training within the } \\
\text { last } 2 \text { years at the BU library? }\end{array}$ & 4 & 19.04 & 16 & 76.2 & 1 & 4.76 \\
\hline $\begin{array}{l}\text { Do you enjoy any health benefits/health } \\
\text { insurance as a casual worker? }\end{array}$ & 14 & 66.6 & 5 & 23.8 & 2 & 9.52 \\
\hline $\begin{array}{l}\text { Is there opportunity for career } \\
\text { progression for you at the library? }\end{array}$ & 14 & 66.6 & 6 & 28.6 & 1 & 4.76 \\
\hline $\begin{array}{l}\text { Are there possibilities for future } \\
\text { career progression at the library? }\end{array}$ & 13 & 61.9 & 5 & 23.8 & 3 & 14.3 \\
\hline $\begin{array}{l}\text { Do you feel treated less fairly than } \\
\text { permanent (regular) employees? }\end{array}$ & 10 & 47.6 & 10 & 47.6 & 1 & 4.76 \\
\hline $\begin{array}{l}\text { Do you feel exploited at the expense } \\
\text { of permanent (regular) employees? }\end{array}$ & 7 & 33.3 & 10 & 47.6 & 4 & 19.04 \\
\hline
\end{tabular}


Table 4 indicates that casual workers in Babcock University library took to casual labour either to keep busy or with the belief that casual labour will bridge them to permanent employment with 33.3\% indication. 14.3\% indicated they took to casual labour due to poverty while $9.52 \%$ are casual workers because of high unemployment.

\section{Discussion of Findings}

The experience with casualization at Babcock university library shows that $60 \%$ of library workers are casual workers. This agrees with the findings of Bodibe [4], Bamidele [3], and Okafor [2] that firms could engage a substantial percentage of employees as casual workers.

Most casual workers in Babcock university library are young persons who have worked between one to three years, with educational qualification ranging from SSCE to first degree. This accords with the position of Kalejaiye [1] who noted that causal work is pervasive among the unskilled persons with low educational qualification.

Majority of casual workers in Babcock university library also enjoy health benefits/health insurance. Although Fourie [7], Bodibe [4] and Kalejaiye [1] indicate casual workers do not receive social wage benefits such as medical benefits, majority of casual workers in Babcock University library showed that they enjoy medical benefits. This is because Babcock University administration has a health insurance policy in place for casual workers which they are entitled to access if they register for it.

Majority also indicated that they have possibilities for future career progression at the library. This is possible because Babcock University administration gives approval for employees to further improve themselves as they work.

Majority of casual workers at the library are satisfied with their work in the library although a majority indicated that they are dissatisfied with their salary. This finding is in agreement with Bamidele [3] who found that casual employment also comes with poor salary and poor wages.

A majority of casual workers at the Babcock University library indicated their dissatisfaction with the vacation time they receive. Bodibe [4] and Kalejaiye [1] also found that casual workers are not entitled to vacation and if they do take vacation, it is at their cost.

\section{Conclusion and Recommendations}

From the study, it could be concluded that casualisaton of labour is fraught with negative effects. To this extent,

Table 3. Level of satisfaction of casual workers in Babcock University library.

\begin{tabular}{|c|c|c|c|c|c|c|c|c|c|c|}
\hline How satisfied are you & CD & $\%$ & $\mathrm{D}$ & $\%$ & CS & $\%$ & $\mathrm{~S}$ & $\%$ & $\mathrm{~N}$ & $\%$ \\
\hline with your work at the library & 1 & 4.76 & - & - & 3 & 14.3 & 13 & 61.9 & 3 & 14.3 \\
\hline with your salary at the library & 10 & 47.6 & 1 & 4.76 & - & - & 2 & 9.52 & 7 & 33.3 \\
\hline with your career progression at the library & 4 & 19.04 & 3 & 14.3 & 3 & 14.3 & 6 & 28.6 & 4 & 19.04 \\
\hline with the vacation time you receive & 5 & 23.8 & 4 & 19.04 & 2 & 9.52 & 5 & 23.8 & 4 & 19.04 \\
\hline with the medical insurance & - & - & - & - & 3 & 14.3 & 8 & 38.1 & 9 & 42.85 \\
\hline
\end{tabular}

CD = Completely Dissatisfied, D = Dissatisfied, CS = Completely Satisfied, S = Satisfied, N = Neutral.

Table 4. Reasons for working as casual workers in Babcock University library.

\begin{tabular}{ccc} 
Reason & Frequency & Percentage \\
High unemployment & 2 & 9.52 \\
To keep busy/while away time & 7 & \\
To bridge to permanent employment & 7 & 33.3 \\
Poverty & 3 & \\
No response & 2 & 9.32 \\
\hline
\end{tabular}


casual workers have little commitment to work as their behaviour to work is tied to their wages and not to the job.

The prevailing unemployment rate has encouraged the use of casual labour in Nigeria. Since it is difficult to secure employment, casual workers preferred staying with employers in order to sustain their livelihood, in spite of poor working conditions and poor salary.

Although casual labour is mainly for the unskilled and for those with low educational qualification, casual workers can enjoy the dignity of working in a legally protected environment.

Casual workers should be given the opportunity to be integrated into the organization as permanent staff when they have satisfied organization appraisals and whenever vacancies become available.

Training should be provided for casual workers to equip them with skills for increased productivity.

In order for casual workers to be committed to their work, employers should engage robust welfare policy for all employees including casual workers in order to get the best from them.

Casual work should be legally protected. The law should provide specific protections for casual workers. Social protection legislation should also cover casual, temporary and all forms of nonregular employment.

Employers should have effective communication with its casual workers so as to stimulate an open and sincere communication in order to avoid disputes at work, and to build cohesive working conditions in the work place.

A structure to provide protection at the end of the employees' working life should be developed to sustain workers during retirement.

\section{References}

[1] Kalejaiye, P. (2014) The Rise of Casual Work in Nigeria: Who Loses, Who Benefits? African Research Review, 8, 156-176. http://dx.doi.org/10.4314/afrrev.v8i1.12

[2] Okafor, E. (2012) Nonstandard Employment Relations and Implications for Decent Work Deficits in Nigeria. African Research Review, 6, 93-108. http://dx.doi.org/10.4314/afrrev.v6i3.7

[3] Bamidele, R. Casualization and Labour Utilization in Nigeria. http://www.ilo.org/public/english/iira/documents/congresses/regional/lagos2011/1stparallel/session1b/casualization.pdf

[4] Bodibe, O., Ed. (2006) The Extent and Effects of Casualisation in Southern Africa: Analysis of Lesotho, Mozambique, South Africa, Swaziland, Zambia and Zimbabwe. A Research Report for the Danish Federation of Workers. www.sarpn.org/documents/d0002568/Effects_Casualisation_Nov2006.pdf

[5] Sheen, V. (2012) Labour in Vain: Casualisation Presents a Precarious Future for Workers. http://theconversation.com/labour-in-vain-casualisation-presents-a-precarious-future-for-workers-8181

[6] Day, M. and Buultjens, J. (2007) Casual Employment and Commitment: A Case Study in the Hospitality Industry. http://www.mngt.waikato.ac.nz/departments/Strategy\%20and\%20Human\%20Resource\%20Management/airaanz/proce edings/auckland2007/066.pdf

[7] Fourie, E.S. (2008) Non-Standard Workers: The South African Context, International Law and Regulation by the European Union. PER, 4. http://www.saflii.org/za/journals/PER/2008/23.html

[8] Kharamin, F. and Siamian, H. (2011) The Survey of Public Library Services for Visually Impaired and Blind in Public Libraries (Case Study: Mazandaran Province Librarians: Iran). International Conference on Future Information Technology IPCSIT, 13, 367-372.

[9] Itsekor, V. and Oyewole, O.J. Digital Literacy Skills as Determinants of Job Satisfaction and Career Progression of Academic Library Staff. http://eblip7.library.usask.ca/docs/EBLIP7\%20Paper\%20Itsekor

[10] Tella, A., Ayeni, O. and Popoola, S. (2007) Work Motivation, Job Satisfaction, and Organisational Commitment of Library Personnel in Academic and Research Libraries in Oyo State, Nigeria. Library Philosophy and Practice (EJournal), 9. http://digitalcommons.unl.edu/libphilprac/118

[11] Ugboma, M.U. and Edewor, N. (2008) Use of E-Mail in Library and Information Services Provision in Higher Institutions in Delta State, Nigeria. Information Technologist, 5, 42-51. 